\title{
Terrain Analysis from Landsat Imagery
}

\section{E. T. Oswald}

Department of the Environment

Canadian Forestry Service

Pacific Forest Research Centre

Victoria, B.C. V8Z $1 \mathrm{M} 5$

\begin{abstract}
An evaluation of the use of unenhanced Landsat-1 imagery for depicting features of the earth's surface, which is important to resource management, was conducted in central British Columbia. Sampling was conducted, using as many as six scales of photography, along with ground observations. Some features, such as water bodies, rivers, drainage systems, mountains, snow fields and contrasting vegetation types, can be readily distinguished. Other features, such as major powerlines, roads and railroads, can often be seen, especially when they pass through forested areas, but may be confused on some land types. Within the forested areas, tonal differences reveal broad age- and density-classes. Lodgepole pine was the only species that could be distinguished with any degree of reliability, and only when it occurred in large pure stands. Landsat imagery is most useful in monitoring dynamic events, such as forest harvesting, alterations in Lake levels, snow distribution and some erosion patterns.
\end{abstract}

\section{Résumé}

L'auteur évalua l'utilisation de l'imagerie Landsat-1 non clarifiée pour illustrer les accidents de la surface de la terre. Cette imagerie est importante pour l'aménagement des ressources et l'auteur couvrit le centre de la ColombieBritannique. II conduisit des échantillonnages, vérifia avec six échelles de photographie et des observations sur le terrain. Quelques accidents tels que les lacs, les rivières, les bassins hydrographiques, les montagnes, les champs de neige et les types contrastants de végétation peuvent être facilement distingués. On peut en voir d'autres tels que les grandes lignes de transmission d'énergie électrique, les routes, les chemins de fer, surtout lorsqu'ils passent à travers des forêts, mais sur certains terrains ils restent invisibles. En forêt, les différences de tons révèlent les grandes classes d'âge et de densité. Le Pin tordu ( $P$. contorta) est la seule essence forestière qui puisse être identifiée, et ce seulement lorsqu'elle existe en grands peuplements purs. L'imagerie Landsat sert surtout à suivre les événements dynamiques tels que l'exploitation forestière, les différences de niveaux des eaux des lacs, la répartition de la neige et quelques effets de l'érosion.

\section{Introduction}

Landsat-1, which was placed in orbit in 1972 by NASA of the United States, has provided a tool for surveying and monitoring features and events on the earth's surface. The technical and logistical features of Landsat have been documented (SaynWittgenstein 1974; Sherman 1974; Warrington 1974). Briefly, four scanners, each sensitive to different wavelengths of reflected light, receive impulses which are sent back to receiving stations on earth on an 18-day cycle for any area. The impulses are stored on digital tapes and can be processed into images. Each image covers an area of $185 \times 185 \mathrm{~km}$, which portrays a synoptic view of a portion of the earth's surface at a scale of approximately $1: 1,000,000$ on a $18.5 \times 18.5-\mathrm{cm}$ format.

The value of satellite imagery for use in resource management, surveying and monitoring must be determined by developing, testing and applying interpretive techniques for different levels of interpretation (Heller 1973). The recognition of an object is largely dependent upon its size and the reflective contrast and distinction (signature) between the object and the background or other objects. Several image enhancement techniques and devices have been developed to assist in recognizing the information content of an image. They range from sophisticated electronic devices, requiring skilled operators, to simple magnification or image combining techniques that can be employed by photo interpreters or by laymen with minimal experience. The advantage of the sophisticated interpretive equipment is the possibility of separating different objects possessing nearly similar signatures. However, this equipment is not readily available to most potential users of the imagery. Often the objects with subtle signature differences are not of particular concern to many aspects of resource management and surveying, and a considerable amount of pertinent information may be obtained from an image by comparing signatures on different wavelength bands and sequential images with an unaided eye, or with simple interpretive techniques.

The following report discusses the application of simple interpretive techniques to Landsat imagery, primarily aimed at revealing terrain features and vegetation patterns in the Interior of British Columbia. The techniques could be practiced or applied by people lacking elaborate equipment; however, experience in photo-interpretation is required. For the current state of knowledge in Canada on the satellite program and on applications of the imagery, Godby (1974) and the Proceedings of the Second Canadian Symposium on Remote Sensing (G. E. Thompson (Ed.), 1974) should be consulted. 


\section{Description of Test Area}

A transect approximately $50 \times 400 \mathrm{~km}$ extending from Albreda $\left(119^{\circ} 10^{\prime} \mathrm{W}, 52^{\circ} 39^{\prime} \mathrm{N}\right)$ and Blue River $\left(119^{\circ} 18^{\prime} \mathrm{W}, 52^{\circ} 06^{\prime} \mathrm{N}\right)$ to Mt. Granville $\left(124^{\circ} 35^{\prime} \mathrm{W}, 50^{\circ} 57^{\prime} \mathrm{N}\right)$ and Mt. Gilbert $\left(124^{\circ} 15^{\prime}\right.$ W, $50^{\circ} 51^{\prime} \mathrm{N}$ ) was selected for study. The landscapes ranged from mountains over $3,000 \mathrm{~m}$ a.s.l. to prairie under $1,000 \mathrm{~m}$ a.s.I. Climatic regimes ranged from dry to wet and warm to cold. Lakes of various sizes occurred in the area and the Fraser River passed through the central portion. Glaciers occurred above $1,800 \mathrm{~m}$ on the west end and 2,100 $m$ on the east end of the transect. Krajina (1969) recognized five biogeoclimatic zones in the area: the Alpine Tundra, the Subalpine Engelmann Spruce - Subalpine Fir, the Interior Western Hemlock, the Interior Douglas-fir, and the Cariboo Aspen - Lodgepole pine - Douglas-fir. Rowe (1972) distinguished five forest regions: the Tundra, the Subalpine, the Columbia, the Montane, and the Grassland.

\section{Methods of Analysis}

Landsat images were analyzed by identifying features on high and low level photography and relating these, along with features portrayed on maps and those observed in the field, to spectral signatures on the satellite images.

Most of the transect was photographed from about $10 \mathrm{~km}$ a.s.I. along two flight lines on July 5 and October 4, 1972. A Wild RC 10 camera, equipped with an 88-mm lens and Kodak 2445 color film, produced $23 \times 23-\mathrm{cm}$ true color photographs at a scale of approximately 1:114,000. Four Vinten cameras, with 76-mm focal-length lenses, produced $70-\mathrm{mm}$ contact photographs in color IR, black and white IR, and the red and green bands of the light spectrum. An RS 14 infrared line scanner with a $127-\mathrm{mm}$ scan produced imagery in the 3 to $5 \mu \mathrm{m}$ wavelengths. Vegetation and landscape features were identified on this photography and related to satellite imagery.

Different vegetation patterns or ecological settings were photographed at low-level, employing a Cessna 180 equipped with two Vinten $70-\mathrm{mm}$ cameras. One camera was equipped with a $76-\mathrm{mm}$ focal-length lens and Kodak 2448 color film, and the other with a 152-mm focal-length lens and Kodak 2403 panchromatic film. A flying height of $3600 \mathrm{~m}$ (a.g.l.) produced contact scales of $1: 48,000$ and 1:24,000 and a height of $300 \mathrm{~m}$ contact scales of $1: 4,000$ and $1: 2,000$.

Forest cover maps were used as an aid for recognizing differences in composition and curcent history of stands. Canada Land Inventory maps served as an aid to landform and soil recognition, but were available for a very small portion of the transect.

Ground surveying was conducted to view some of the accessible vegetation patterns and to identify objects discernible on the photographs and satellite images.

The following satellite images of the study area were obtained: E-1294-18313, May 13, 1973; E-1295-
18371, May 14, 1973: E-1384-18302, August 11, 1973; E-1385-18360, August 12, 1973; E-1690-18234, June 13, 1974, and E-1691-18293, June 14, 1974. Winter images were not used because of continuous snow cover throughout most of the season.

Diazo contact prints (Ryerson 1973; Warrington 1974) were made of each black and white $18.5 \times 18.5-\mathrm{cm}$ image transparency. Three colors (red, blue and green) of diazo film were exposed from each image. These were overlaid in different color combinations to enhance some features and to locate alteration of features, such as current logging, on sequential scenes. A color additive viewer, which is a more sophisticated and versatile tool for producing color composites similar to the diazo prints, was used to make composites of some scenes.

\section{Analysis of Imagery}

Some landscape features are easily identified on the Landsat images by comparing the signatures of the features on the images representing the four spectral wavelength bands constituting a scene. Objects, such as water bodies, rivers, drainage patterns, mountains, perpetually wet meadows covered with short non-shrubby vegetation and irrigated hay fields, are readily distingguishable on band 7 and usually on band 6 . Some major vegetation types, such as forest land versus grassland, and openings within forest stands, such as logged areas, can be distinguished on band 5 and often on band 4 (Oswald 1974). Snow fields can be discerned on all bands but are most reliably determined by comparing the signatures on different bands (Golding 1974) or, better still, scenes of different dates to avoid confusion with clouds. Melting snow produces a dark color on band 7 due to the water content, but is white on band 4 . Clouds, especially cumulus types, frequently appear much like snow fields when they occur at mountain summits; however, the longer wavelengths, i.e., band 7 , have greater penetrating power of clouds than shorter ones and comparison of short and long wavelength images (i.e., bands 4 and 7 ) aids in distinguishing clouds from snow. Other aids to distinguishing clouds include the shadow produced by cumulus clouds and sharp lines crossing valleys. Some of these features are portrayed in Fig. 1, which is the image of band 5 covering the central portion of the study area. Fig. 2 illustrates reference features for Fig. 1.

Major pathways, such as roads, railroads and powerlines, are discernible on bands 4 and 5 , especially where they pass through forested areas (Figs. 1 and 3). The distinction among the different pathways may not always be possible; however, the shape often serves as an aid. Powerlines are placed in straight lines for considerable distances regardless of landform; pipelines may be similar where soil depth permits, but frequently follow slope patterns and bend more to avoid rock outcrops, whereas roads and railroads usually follow valleys and appear serpentinatious. Seismic lines (Wallace and Peaker 1974), if they are 
prominent as in some parts of British Columbia, may appear much like power lines but do not occur in the study area. Railroads sometimes have more straight stretches than automobile roads but often run essentially side by side. Differences between paved and unpaved roads cannot be discerned.

The forested areas exhibit tonal differences which indicate variations in stands. Dark tones are produced by dense stands of old-growth trees. Mature and older stands of spruce, hemlock, fir and cedar have darker tonal signatures than lodgepole pine or mixed lodgepole pine and Douglas-fir stands. Cedar may produce light tones similar to lodgepole pine, but no large stands containing a predominance of cedar were found. In Fig. 1, the even medium gray tone extending from Green Lake northward and westward almost to the Fraser River, and extensive patches on the west side of the Fraser River, are lodgepole pine with a very small proportion of other tree species. These areas appear as a rusty green color in Fig. 4, a color composite of bands 5, 6 and 7 . Krajina (1969) indicates that the areas between Green Lake and the Fraser River and some areas on the west side of the Fraser River (Fig. 5) belong to the Engelmann Spruce - Subalpine Fir Biogeoclimatic Zone; however, field checking revealed that the current forest in these areas is nearly pure lodgepole pine, possibly because of the successional stage. The darker tones in association with the mountains at the lower portion of the image (Figs. 1 and 4), much of which is under snow, are produced by a predominance of Engelmann spruce and subalpine fir.

Clearings, natural or man-made, within the forested areas are readily observable on bands 4 and 5 (Figs. 1 and 3). Those resulting from logging operations are the most recognizable because of the straight boundaries, usually in a rectangular shape, and frequently the presence of logging roads. Tonal differences within logged areas arise from two causes, 1) the density of trees left standing following cutting, which varies from zero to several per acre, since most areas were selectively logged for trees above a certain minimum size, and 2) degree of reforestation. Clear-cut areas, such as the summit of Mt. Timothy (Figs. 1 and 2), appear whiter than areas selectively logged during the same year. Because of the selective cutting practice, the age of cutting or degree of reforestation cannot be reliably estimated by viewing a single set of images. Current logging operations can easily be detected by comparing sequential images (Figs. 3 and 7), and subsequent images may be used to monitor revegetation.

Openings in the forested areas for reasons other than logging occur but lack a distinctive pattern which would reveal their purpose. Some irregular forest clearings visible on bands 4 and 5 , with a convergence of roads and service lines, indicate the occurrence of towns, residential or industrial sites (Fig. 3), and the size can be estimated from the size of the clearing. Towns present in the study area have populations of less than 5,000 , are usual- ly spread out, and therefore lack the distinctive pattern of larger cities. Rectangular or variable shaped blocks with straight boundaries in association with valleys in inhabited areas are mostly pastures or hay fields. Burned areas are recognizable on bands 6 and 7 during summer and on bands 4 and 5 in winter.

Lakes and rivers are quite evident as black tones on bands 6 and 7 . Siltation or algal growth causes the dark tones, characteristic of water bodies, to fade on the shorter wavelength bands (Figs. 6 and 7). Comparison of spectral signatures during the course of the year best reveals the degree of siltation, which is an indicator of erosion within the drainage system. Most of the lakes draining the perpetual ice fields in the lower left-hand portion of Fig. 6 are silted throughout the year, but reveal some differences conceivably due in part, to depths. Downton and Carpenter lakes, although dammed, are generally shallow, as indicated by comparing bands 4 and 7 in spring and autumn images, and are silted most of the time. Gun Lake, which lies adjacent to the dam on Downton Lake, reveals no siltation, presumably because it is deeper and receives runoff from a smaller, perhaps more stabilized area. Another example of lake dynamics is indicated by Felker and Chimney lakes (Fig. 7). These lakes occur in the same drainage and are separated by a distance of less than a kilometer. Both have dark gray to black spectral signatures on bands 5,6 and 7 in spring and early summer images. In Chimney Lake, however, the late summer image (mid-August) reveals

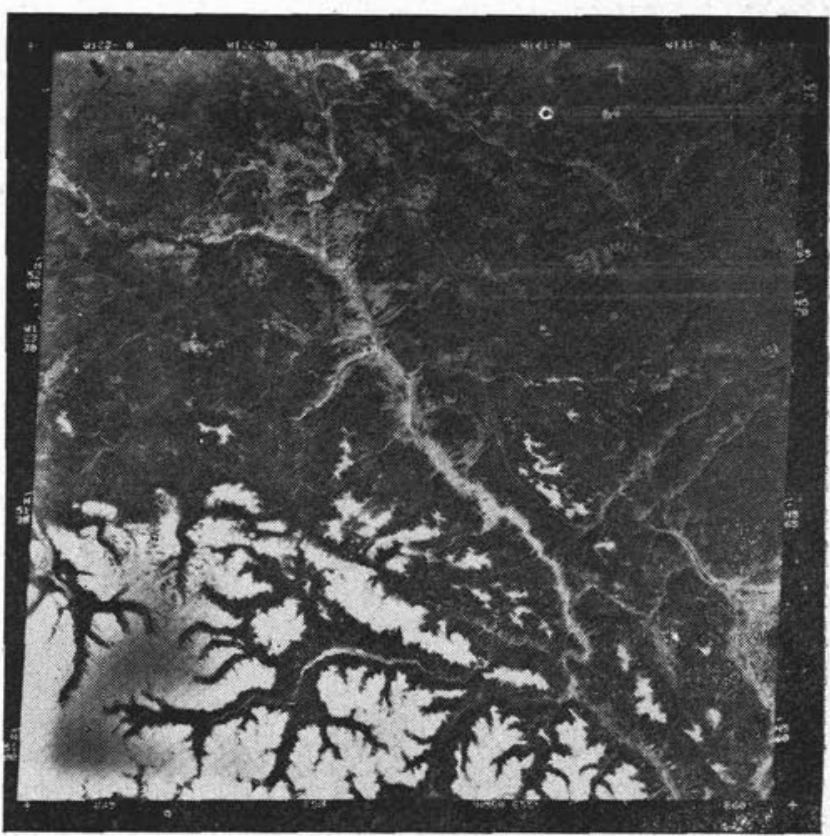

Figure 1. ERTS E-1691-18293-5, June 14, 1974. Note grassland along Fraser River, snow fields in lower left portion, and forest cover on remainder. The larger, more distinct lakes are visible and light gray patches with straight boundaries are logged areas. The prominent line traversing from top to bottom on the right side of the Fraser River is a powerline $145 \mathrm{~m}$ wide. Other powerlines, pipelines and roads are visible on the right side of the image. See Fig. 2 for reference features. 


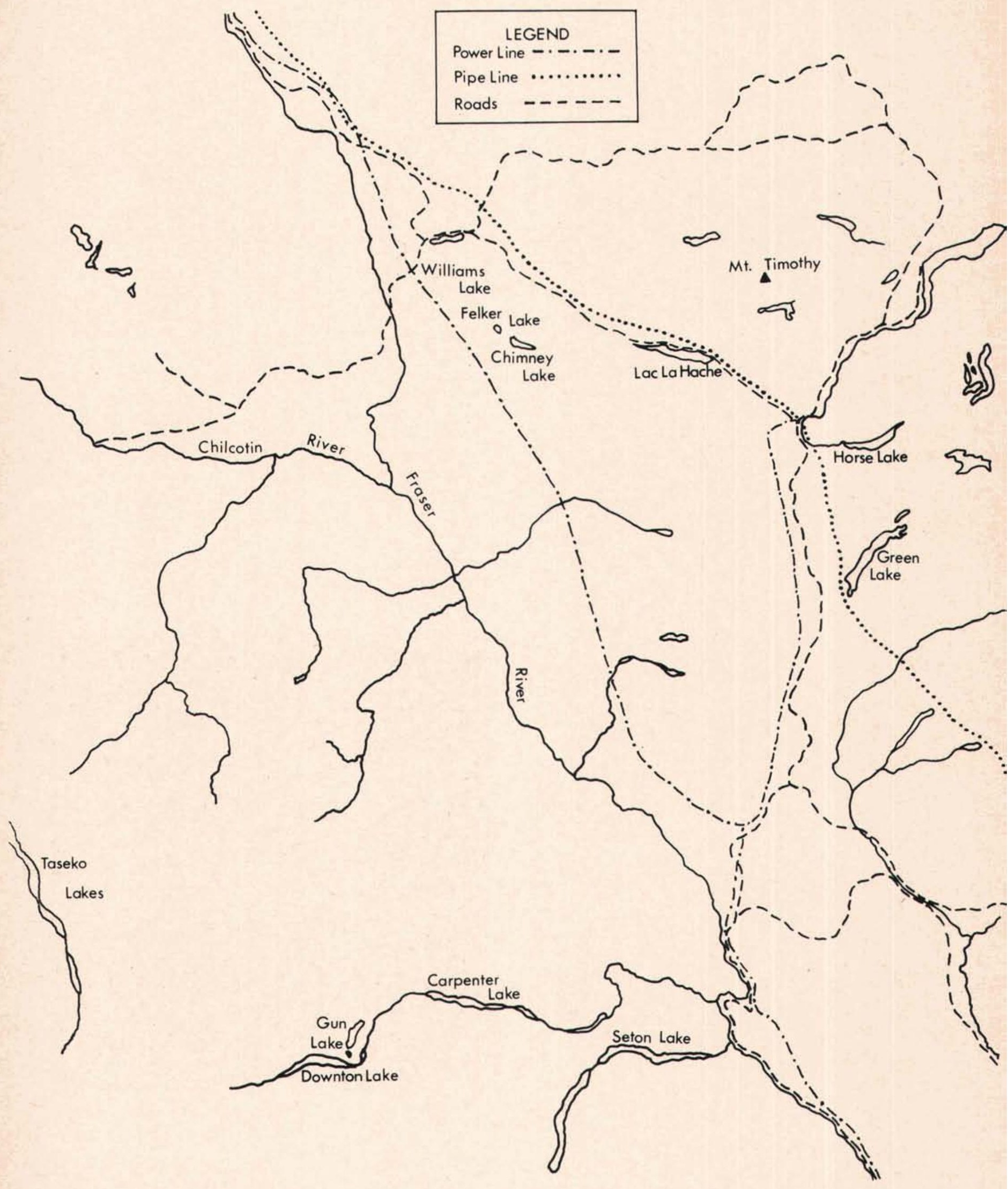

Figure 2. Map of central portion of transect indicating reference features. 
a different reflectance, presumably due to lowering of the lake level and development of vegetative growth, which does not occur in Felker Lake.

Within the grassland area, few features can be discerned, except for topographic differences, drainage systems and irrigated fields (Fig. 7). The grassland portion of the area under investigation is used primarily as open-range for livestock; therefore, different grazing pressures of pastures cannot be evaluated.

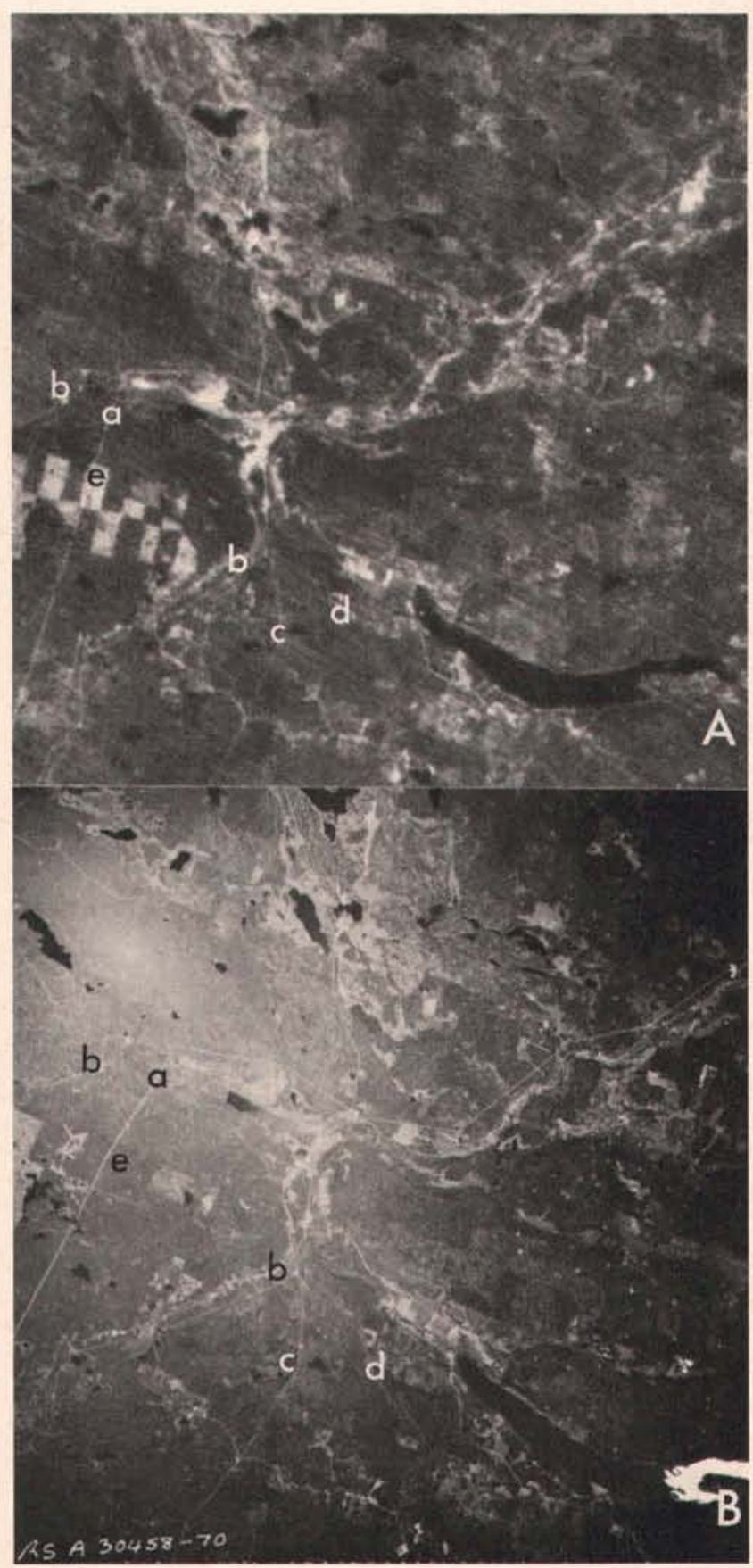

Figure 3. $A$ is an enlarged portion of E-1691-18293-9, June 14,1974 , showing service lines passing through 100 Mile House, B is high-altitude photo RSA3045870 . July 5,1972 , of same area. See Fig. 1 for reference features. Note powerlines (a), roads (b), pipeline (c), railroad (d) and areas logged between imagery dates (e).

\section{Applications}

Landsat imagery can be useful, without utilization of elaborate equipment, for delineating several terrain features which have importance to broad scale resource planning and management (Lee 1974; Kirby 1974; Gimbarzevsky 1974). Among the more easily recognizable features are water bodies, watershed and drainage systems, mountainous topography, landform patterns, grassland versus forest land and snow fields. In addition, accurate planimetric maps showing the placement of discernible natural and man-made features can be produced. Larger, more distinct, man-made features, such as major automobile and railroad corridors, powerlines and seismic lines, can be precisely delineated, especially where they pass through forested areas.

Several dynamic or catastrophic events can be monitored through sequential imagery (Murtha 1974; Moore 1974a; b, International Symposium on Remote Sensing of Environment, 1974). Most notable of these events applicable to the study area are forest harvesting operations, forest fires, construction of major corridors, lake levels, some erosion and landslide patterns, snow accumulation and melting, and some agricultural patterns.

With knowledge of the area, more specific interpretations can be made from small-scale remote sensing. The degree of forest closure can be used for rating stocking classes if the species and terrain features are known. This can be utilized to rate reforestation if the age of logging is known,

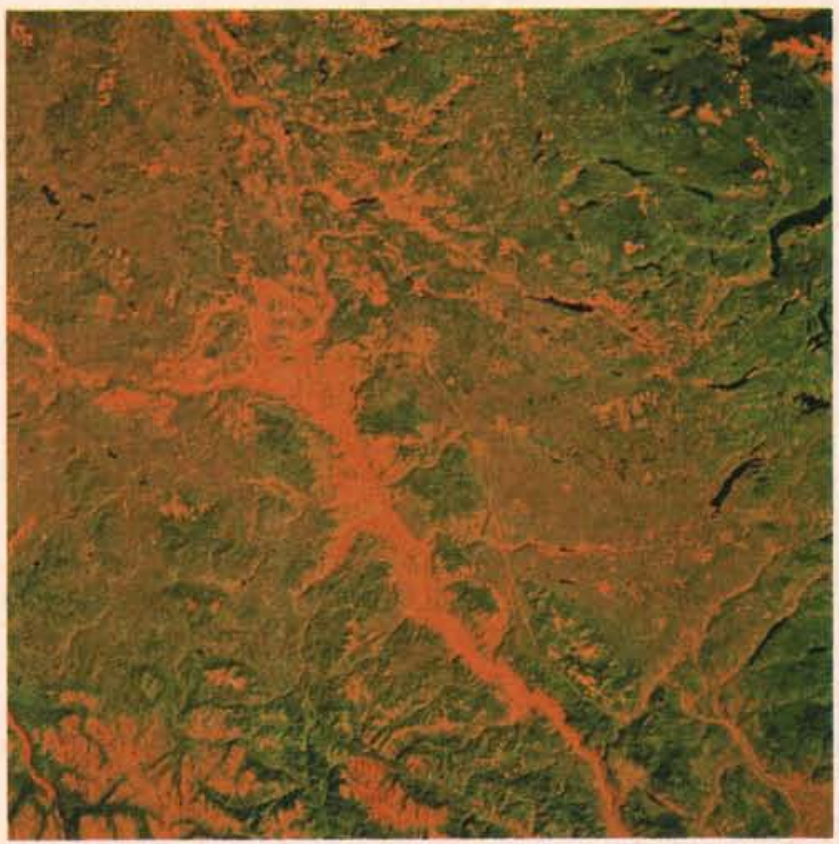

Figure 4. Color combination of bands 4, 6, 7 of E-1385-18360, August 12, 1973. See Fig. 2 for reference features and Fig. 5 for vegetation zones. The rusty green color is lodgepole pine, bright green is mostly Douglas-fir and western hemlock, dark green is subalpine fir and Engelmann spruce and overmature mixed stands, the orange color along the Fraser River is grassland. Note color of Taseko and Chimney Lakes and Fraser River, which are turbid, in comparison to other water bodies. 
but may require comparison of summer and winter images to mask deciduous undergrowth, and the amount of residual material left after selective logging would also have to be known. Broad agedgroup stands, e.g. regeneration, immature, mature and overmature, can often be recognized on the basis of tone or color differences. To some extent, species determinations can be made of nearly pure stands or uniform mixed stands.

Resource inventories can be conducted by employing a multistage hierarchical photographic sampling system (Simonson et al. 1973). For example, units of homogenous signatures can be delineated on the satellite imagery. High altitude or small scale photography of a portion of each unit could be conducted to describe the terrain and other features recognizable at the scale of the photography. Low level photography of portions of the terrain units could be obtained for such detailed analysis as species identification and volume estimates. The area of land photographed at each level would decline as the scale of photography increases; however, the variability within a unit would determine the aerial coverage necessary to adequately describe the features within the unit. Such systems as the Probability Proportional to Size system (Langley 1969; Rogers et al. 1974), the four stage resource inventory system of Legge et al. (1974), or the double sampling system described by MacLean (1972) have been demon-

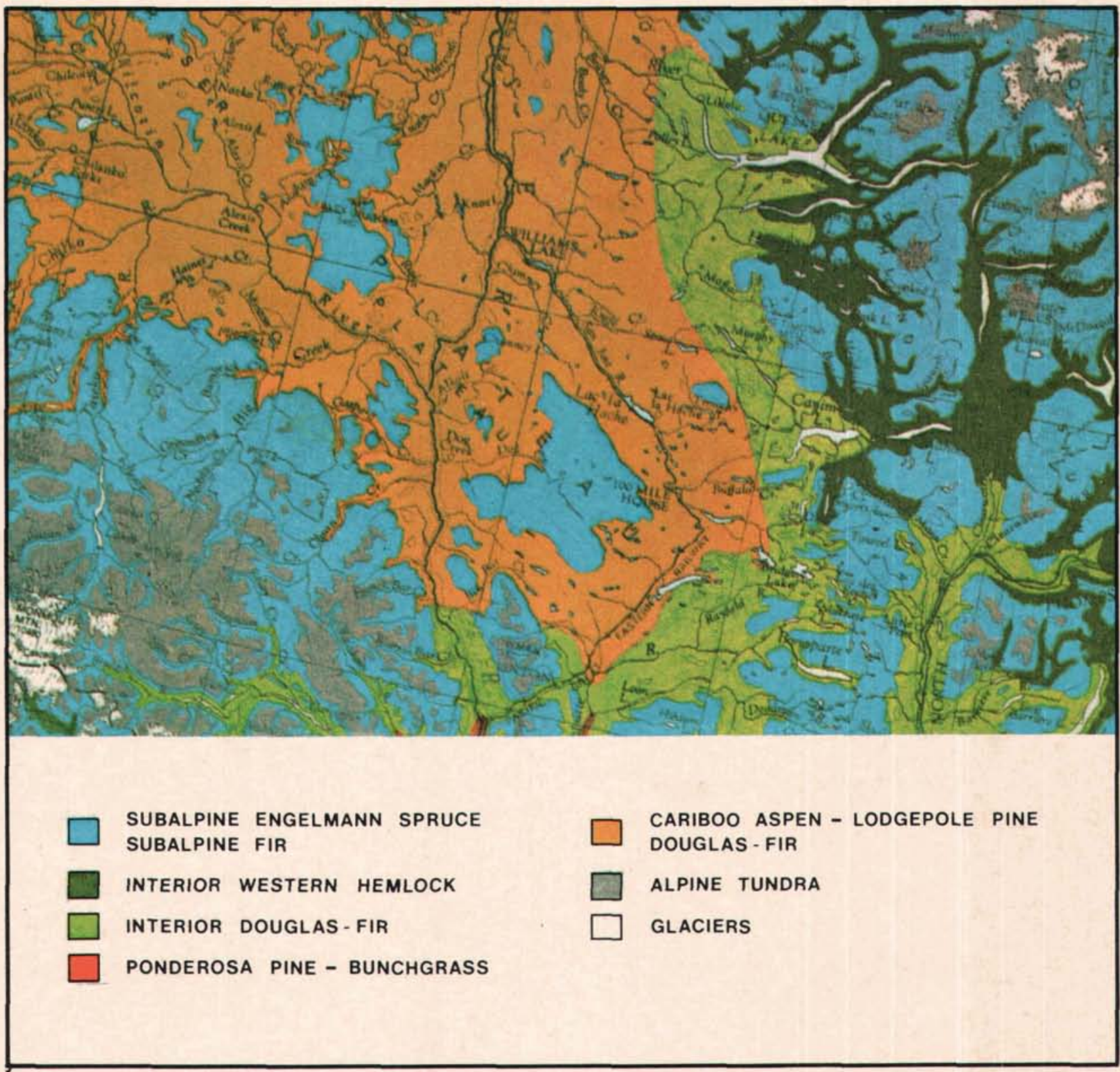

Figure 5. Portion of Krajina's Biogeoclimatic Zone map showing the zones of the study area. Compare to Figs. 1 and 4 .

1-Cariboo Aspen - Lodgepole Pine - Douglas-fir 2-Subalpine Engelmann Spruce - Subalpine Fir 3-Interior Douglas-fir 4-Interior Western Hemlock (dark tone) 5-Alpine Tundra 
strated. Not only is this type of inventorying efficient and economical, the results can be just as valid as the conventional methods used in the past.

Satellite imagery is not the answer to all resource inventorying or planning and management decision making. It does, however, provide an additional tool applicable to many aspects of resource manipulations; therefore, it is worthy of critical evaluation for whatever use can be made of it. Through such a procedure, recommendations and specifications can be made for future satellite systems to further satisfy the requirements of an ever-changing, increasingly demanding population in an economical and expedient manner.

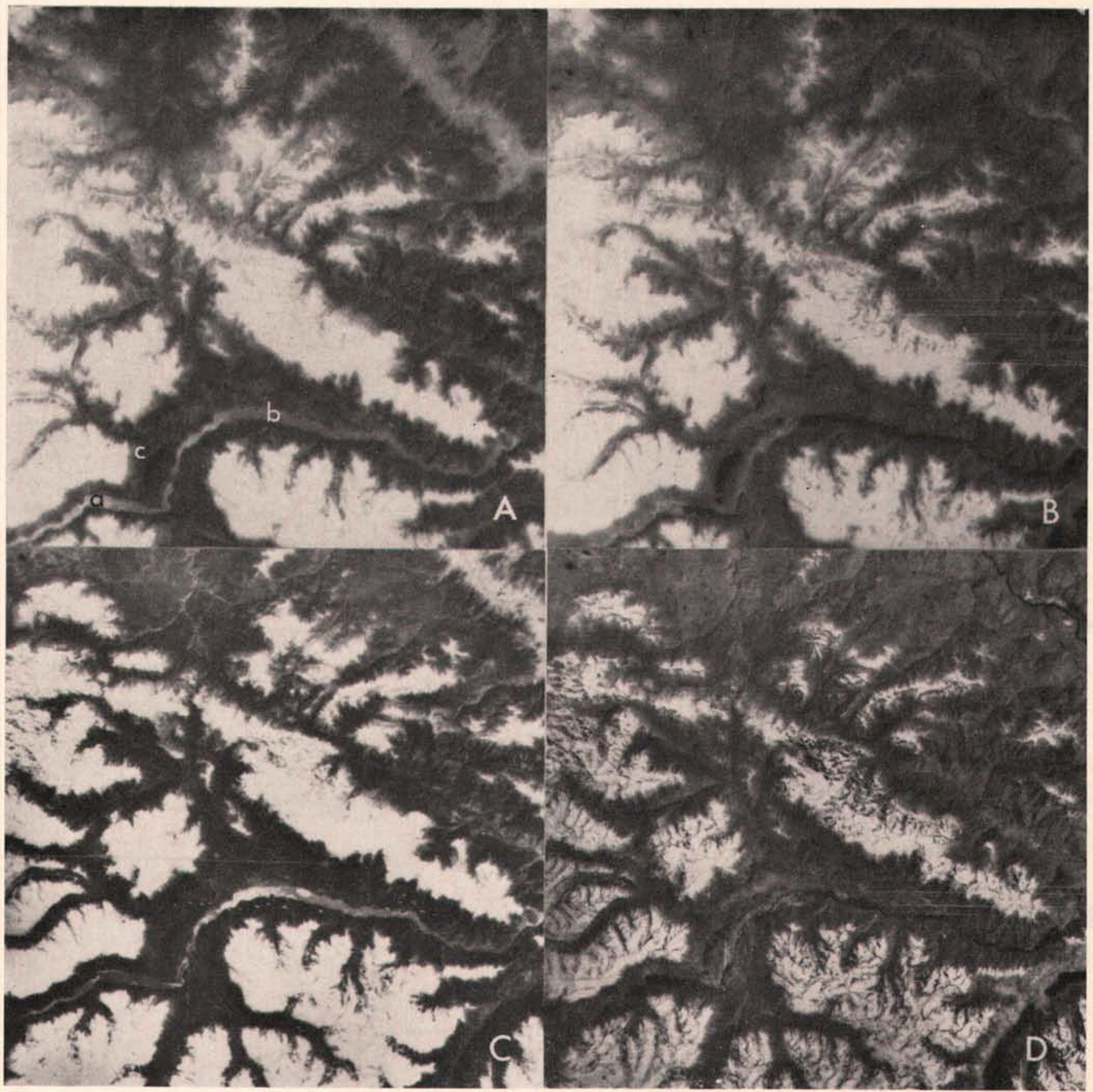

Figure 6. $A$ and $B$ are portions of $E-1295-18371$, bands 5 and 6 respectively. May 14, 1973; C and D are of E-1691-18293, bands 5 and 7 respectively, June 14 , 1974. Note water levels and siltation of Downton (a), Carpenter (b) and Gun (c) lakes. Also, small lakes are visible on bands 6 and 7 but not on band 5 . Differences in the snow fields between the two bands is evident because of the greater penetrating power of the longer wavelengths. 
Figure 7. $A$ and $B$ are portions of E-1385-18360-5, 7 respectively, August 12, 1973; C and D are portions of E-1691-18293-5,7 respectively, June 14, 1974. Note reflectance regime in Chimney Lake (a), Also note wet meadows (b) and irrigated meadows (c) appearing as white areas on band 7 , and areas logged (d) between August 12, 1973 and June 14, 1974.

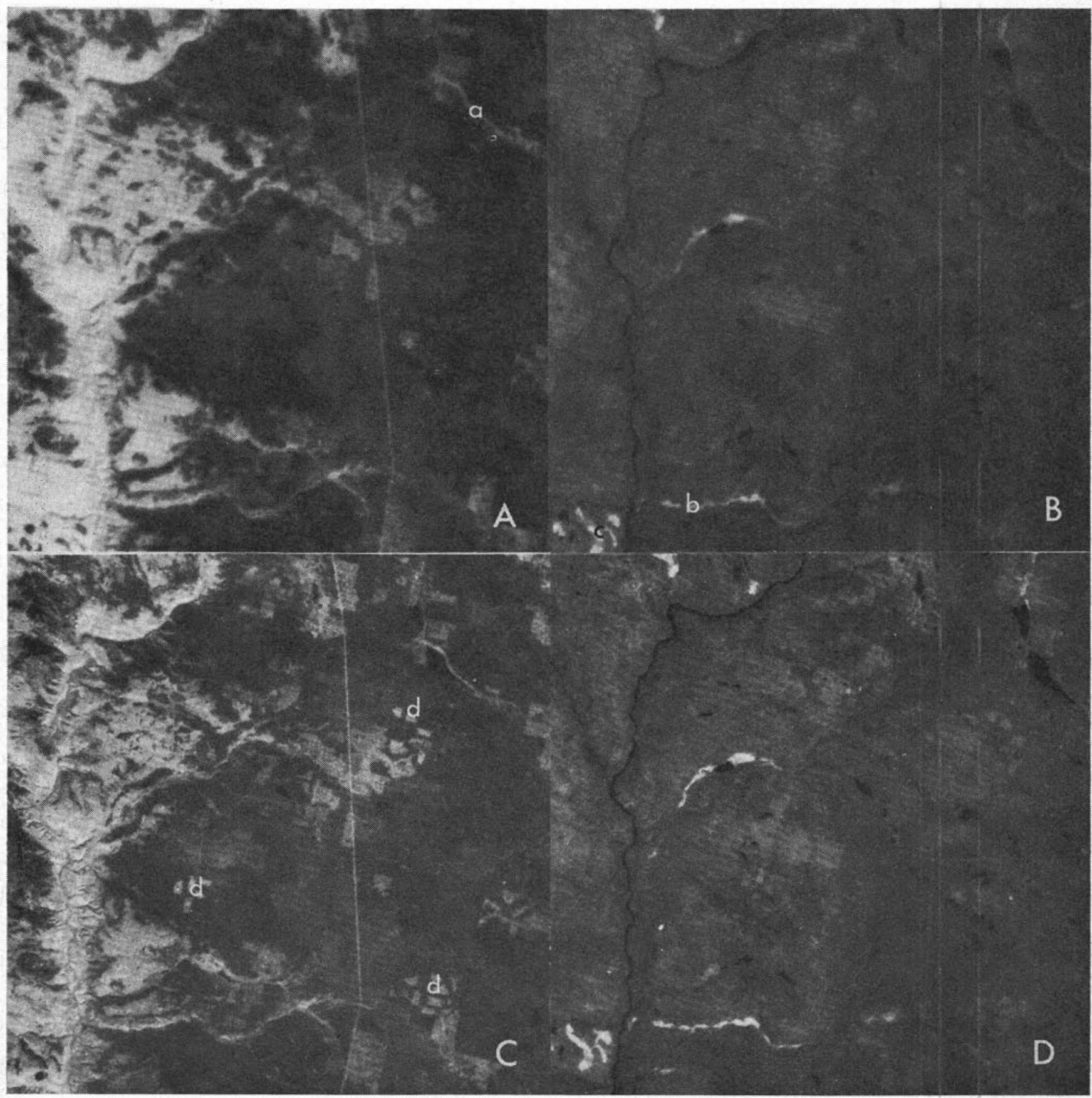

\section{References}

Gimbarzevsky, P. 1974. Interpretation of ERTS imagery in biophysical surveys. The Canadian Surveyor 28: 180-186.

Godby, E. A. 1974. Acquisition and use of ERTS-1 data in Canada. Paper B.1.2 presented at the Seminar on Space Applications of Direct Interest to Developing Countries, San Jose dos Campos, Brazil.

Golding, D. L. 1974. Snow cover and melting snow from ERTS imagery. The Canadian Surveyor 28: 128-134.

Heller, R. C. 1973. Analysis of ERTS imagery - Problems and promises for foresters. pp. 373-393. Proceedings Symposium IUFRO S605 G, Freiburg, Germany.

International Symposium on Remote Sensing of Environ- ment, 9th. Vols I-III. Center for Remote Sensing Information and Analysis. Environmental Research Institute of Michigan, Ann Arbor, Michigan. April 13-19, 1974.

Kirby, C. 1974. Monitoring forest management operations. The Canadian Surveyor 28: 142-146.

Krajina, V. J. 1969. Ecology of forest trees in British Columbia, Ecology of Western North America 2(1): 1-147, Department of Botany, University of British Columbia, Vancouver.

Langley, P. G. 1969. New multi-stage sampling techniques using space and aircraft imagery for forest inventory. pp. 1179-1192. Proceedings of Sixth International Symposium on Remote Sensing. University of Michigan, Ann Arbor, Mich. 
Lee, Y. J. 1974. Monitoring forest management operations. The Canadian Surveyor 28: 135-141.

Legge, A. H., D. R. Jaques, C. E. Poulton, C. L. Kirby and P. Van Eck. 1974. Development and application of an ecologically based remote sensing legend system for the Kananaskis, Alberta, remote sensing test corridor (Subalpine forest region). International Society for Photogrammetry, Banff, Alberta.

MacLean, C. D. 1972. Photo stratification improves Northwest timber volume estimates. U.S.D.A. Forest Service Research Paper PNW-150.

Moore, W. C. 1974a. Tornado damage to forests: Sudbury, Ontario. The Canadian Surveyor 28: 126-127.

Moore, W. C. 1974b. Detection and delineation of natural disasters: Landslides and floods. The Canadian Surveyor 28: 180-186.

Murtha, P. A. 1974. Detection of $\mathrm{SO}_{2}$ fume damage to forests on ERTS-1 imagery. The Canadian Surveyor 28: 167-170.

Oswald, E. T. 1974. Evaluation of ERTS imagery for vegetation interpretation in British Columbia. The Canadian Surveyor 28: 147-154.

Rogers, R. A., D. P. Paine and G. Miller. 1974. A. multi-stage forest inventory using ERTS. Paper presented at "Applications of Satellite and Airplane Remote Sensing of Natural Resources in the Pacific Northwest" Symposium, Olympia, Washington.

Rowe, J. S. 1972. Forest Regions of Canada. Department of
Environment, Canadian Forestry Service Publ. No. 1300. Ryerson, R. A. 1973. Diazo composites: An inexpensive too for ERTS imagery analysis. C.C.R.S., Tech. Note: 73-75.

Sayn-Wittgenstein, L. 1974 The ERTS experiments of the Canadian Forestry Service. The Canadian Surveyor 28: 110-112.

Sherman, J. C. 1974. Atlas of a single ERTS image, Puget Sound, Washington State. U.S. Dept. of Interior, Geological Survey. Cont. No. 14-08-0001-12864.

Simonson, G. H. et al. 1973. The comparative evaluation of ERTS-1 imagery for resource inventory. In Land Use Planning, Interim Report for Period March - August 1973, NASA, Goddard Space Flight Centre.

Thompson, G. E. (Ed.). 1974. Proceedings of the Second Canadian Symposium on Remote Sensing. Vols. 1 and 2. University of Guelph, Guelph, Ontario. April 29-May 1, 1976.

Wallace, W. L. and J. P. Peaker. 1974. Seismic lines on ERTS-1 images. The Canadian Surveyor 28: 177.

Warrington, P. 1974. Technical aspects of the satellite. pp. 1-8. In P.D. Warrington (Ed.), The B.C. ERTS-1 Users Handbook. Victoria, British Columbia.

Warrington, P. D. 1974. The diazo process as a means of extracting information from ERTS-1 multispectral data. pp. 40-46. In P. D. Warrington (Ed.) The B.C. ERTS-1 Users Handbook, Victoria, British Columbia.

\section{LIGHTNING FIRE PREDICTION NETWORKS}

*"A system to predict the occurrence of lightning caused forest fires" P. H. Kourtz, information report FF-X-47 Forest Fire Research Institute, Canadian Forestry Service Ottawa, Canada K1A $\mathrm{OH} 3$ - March 1974.

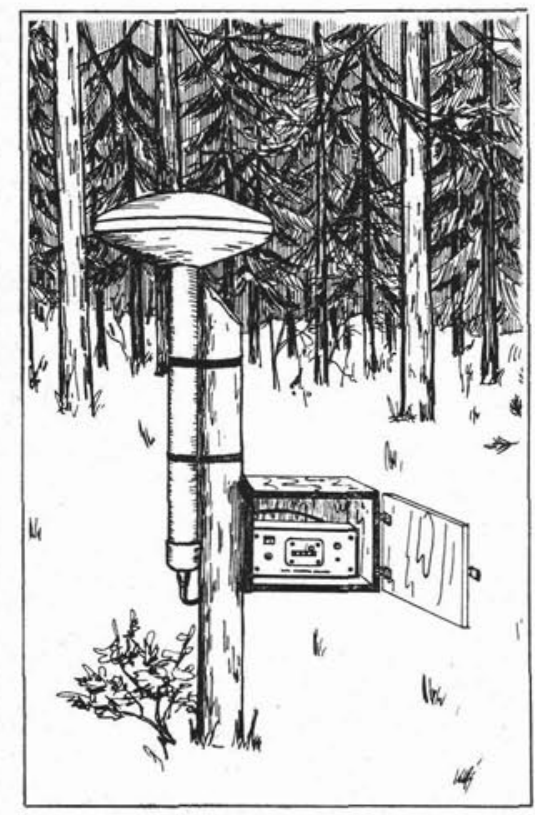

The successful outcome of joint government and industrial research, * lightning caused fire prediction networks based on the correlation between the Duff moisture code combined with lightning strokes in a given area, and the number of lightning caused forest fires in that area, are now in extensive use throughout Ontario and in other provinces.

The Duff moisture code is derived from standard meteorological data while the number of lightning strokes in a twenty mile radius is obtained from highly reliable repeatable lightning stroke counters. Improved, variable-range counters are now available from stock for the 1976 fire season. Designed and manufactured in Canada by Quality Technology Limited, the counters have high discrimination against cloud-to-cloud lightning strikes and ignition noise.

$\begin{array}{ll}\text { DETECTION METHOD: } & \begin{array}{l}\text { Triggered by electric field rate of change } \\ \text { and duration. } \\ \text { Can be set for } 10,15,19,25,32,42,54,70,\end{array} \\ \text { RANGE: } & \begin{array}{l}\text { or } 90 \mathrm{~km} \text { for sites below } 1500 \text { metres. } \\ \text { The effective range of LSC-202 increases } \\ \text { with height above mean sea level. For up }\end{array} \\ \text { to approximately } 1500 \text { metres elevation, } \\ \text { HEIGHT: } & \begin{array}{l}\text { range setting } 5 \text { gives a range of } 32 \mathrm{~km} \text {. } \\ \text { Thaintain this range the range setting }\end{array} \\ & \text { should be reduced by one digit for every } \\ \text { approximate } 500 \text { metre increase in height. } & 4 \text { digit electromechanical counter to 9999; } \\ \text { Battery condition meter. } & \\ \text { BISPLAYS: } & \end{array}$

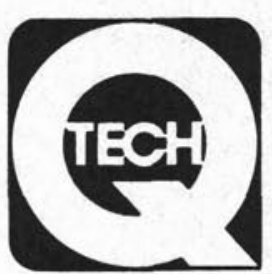

For more information on lightning stroke counters and other instruments write to: Marketing Manager, SOTAIRE LIMITED, 7510 Tyrol Street, Brossard, P.Q. - Tel.: (514) 672-2045.
WORLD-WIDE MARKETING AGENTS FOR

QUALITY TECHNOLOGY LIMITED 